\title{
The Palaeolithic and Mesolithic Periods
}

\author{
Article
}

Accepted Version

Hosfield, R. (2017) The Palaeolithic and Mesolithic Periods. Archaeological Journal, 174 (S1). pp. 10-11. ISSN 2373-2288 doi: https://doi.org/10.1080/00665983.2017.1300851 Available at https://centaur.reading.ac.uk/72883/

It is advisable to refer to the publisher's version if you intend to cite from the work. See Guidance on citing.

To link to this article DOI: http://dx.doi.org/10.1080/00665983.2017.1300851

Publisher: Taylor \& Francis

All outputs in CentAUR are protected by Intellectual Property Rights law, including copyright law. Copyright and IPR is retained by the creators or other copyright holders. Terms and conditions for use of this material are defined in the End User Agreement.

\section{www.reading.ac.uk/centaur}

\section{CentAUR}

Central Archive at the University of Reading

Reading's research outputs online 
Palaeolithic and Mesolithic Wiltshire

Like Britain as a whole, the Palaeolithic (c. 950,000-11,600 BP $)$ archaeology of Wiltshire is dominated by river valley finds, and by artefacts from the Lower Palaeolithic (c. 950,000-250,000 $\left.\mathrm{BP}^{1}\right)$. While many of these finds were made during the $19^{\text {th }}$ and early $20^{\text {th }}$ century heyday of handdug gravel extraction and Victorian urban expansion (Wymer 1999), more recent discoveries have also been made. Of particular note is the late Lower Palaeolithic landscape exposed at Harnham through road construction (Bates et al. 2014). Excavations revealed in situ handaxe manufacture and associated palaeoenvironmental evidence in a riverbank setting, dating to c. 250,000 BP. The site is highly significant for (i) enhancing understanding of the transition between Lower Palaeolithic Acheulean (handaxe) industries and the Levallois technologies of the Middle Palaeolithic; (ii) demonstrating the ability of hominins, either $\mathrm{H}$. heidelbergensis or perhaps early Neanderthals, to tolerate cool climates at high latitudes; and (iii) re-emphasising the key relationship between infrastructure projects and early prehistoric landscapes and the importance of thorough archaeological evaluations.

The majority of Wiltshire's Lower Palaeolithic artefacts have been recovered from river terrace deposits (the valley-side remnants of ex-floodplains abandoned over the course of the Pleistocene through river downcutting), particularly those associated with the Bourne, Avon, Nadder and Wylye confluences in and around Salisbury, and especially at Bemerton and Milford Hill. Wymer (1999) saw these concentrations as evidence for focused hominin activity, in contrast to the relative paucity of finds from the chalk-stream landscapes upstream of Salisbury, but there is also increasing concern at the partial view of Palaeolithic landscapes and hominin behaviour that such evidence provides (e.g. Pope et al. in press). Recent RAl-funded re-investigations of Knowle Farm, west of Froxfield, by Reading University (Rob Hosfield and Chris Green) were motivated by this bias, and are currently reinvestigating the solifluction deposits and possible interfluve origins of the site's rich handaxe assemblage (see also Froom 1983).

The last few decades have seen important developments in our understanding of changing Mesolithic landscapes and habitats in Wiltshire (c. 9,600-4,000 cal. BC $\left.{ }^{1}\right)$. Pollen and molluscan data from tree-throw pits and other contexts have demonstrated the timing and character of vegetation development, commonly in the form of a shift from open, marshy conditions to full woodland. This occurred at around 7,500 cal. BC in the Upper Kennett, with evidence from a range of sites and settings across that landscape suggesting that such woodland was ubiquitous by the mid-Holocene (Evans et al. 1993). Further insights will also be forthcoming from Reading University's current research at and around Marden Henge (Jim Leary, Martin Bell and Amanda Clarke).

Wiltshire's widespread Mesolithic record, concentrated around Salisbury and in the north-west and north-east of the county, is dominated by sites with small numbers of artefacts, but there are also more significant assemblages and sites highlighting hunter-gatherer behaviour in this period. Of particular note are Cherhill (late Mesolithic artefacts, c. 4450-3750 cal. BC, in association with charcoal, animal bone, and closed woodland, and earmarked as a possible hunting camp: Evans \& Smith 1983; Whittle 1990), Castle Meadow, Downton (tool manufacture, hearths, and stake-hole traces of possible lightweight, temporary structures; Higgs 1959) and most recently Blick Mead (see below). Early Mesolithic postholes have been documented at Stonehenge (see below) and other sub-soil features (e.g. ditches and pits) have been recorded elsewhere, such as at Strawberry Hill in 
the north of the county (Allen \& Gardiner 2002). Alongside excavated assemblages, understanding of the Wiltshire Mesolithic has also been greatly enhanced by surface collections arising from the sustained work of dedicated local archaeologists (e.g. around Knighton; Froom 1965). These collections have emphasised localised concentrations and a wider range of associations between artefacts, hunter-gatherer behaviours, and different landscape settings. While surface collections can sometimes raise interpretive problems, e.g. through selective sampling, they can also draw our attention to the potential of adjacent or adjoining depositional contexts which might otherwise receive little attention.

${ }^{1}$ Based on dates from sites across Britain, rather than Wiltshire specifically.

For references and further reading:

Allen, M.J. \& Gardiner, J. 2002. A sense of time - cultural markers in the Mesolithic of southern England? In B. David \& M. Wilson (eds.) Inscribed Landscapes: Marking and Making Place: 139153. University of Hawaii Press.

Bates, M.R., Wenban-Smith, F.F., Bello, S.M., Bridgland, D.R., Buck, L.T., Collins, M.J., Keen, D.H., Leary, J., Parfitt, S.A., Penkman, K., Rhodes, E., Ryssaert, C. \& Whittaker, J.E. 2014. Late persistence of the Acheulian in southern Britain in an MIS 8 interstadial: evidence from Harnham, Wiltshire. Quaternary Science Reviews 101: 159-176.

Evans, J.G. \& Smith, I.F. 1983. Excavations at Cherhill, North Wiltshire, 1967. Proceedings of the Prehistoric Society 49: 43-118.

Evans, J.G., Limbrey, S., Máté, I. \& Mount, R. 1993. An environmental history of the upper Kennet valley, Wiltshire, for the last 10,000 years. Proceedings of the Prehistoric Society 59: 139-95.

Froom, F.R. 1965. The Mesolithic around Hungerford. Parts IV-V. Transactions of the Newbury District Field Club 11(3): 45-50.

Froom, F.R. 1983. Recent work at the Lower Palaeolithic site at Knowle Farm, Bedwyn. Wiltshire Archaeological and Natural History Magazine 77: 27-37.

Higgs, E S. 1959. The excavation of a Late Mesolithic site at Downton, near Salisbury, Wilts. Proceedings of the Prehistoric Society 25: 209-232.

Pope, M., Blundell, L., Scott, B. \& Cutler, H. In press. Behaviour and process in the formation of the North European Acheulean record: Towards a Unified Palaeolithic Landscape Approach. Quaternary International.

Whittle, A. 1990. A model for the Mesolithic-Neolithic transition in the upper Kennet valley, North Wiltshire. Proceedings of the Prehistoric Society 56: 101-110.

Wymer, J.J. 1999. The Lower Palaeolithic Occupation of Britain. Trust for Wessex Archaeology Ltd: Salisbury. 